\title{
Kropslig subjektivering
}

\section{Af Sarah Højgaard Cawood og MALOU JUELSKJÆR}

Hvordan skal vi gribe kroppens betydning for, hvordan og hvad vi bliver til som subjekter som en tilblivende, relationel, sedimenterende og forandrende proces? Og hvordan vil en analyseproces se ud med et saidant kropsperspektiv?
I antropologi, estetisk teori, psykologi har kroppen i de sidste 10-15 år været et hot og omstridt teoretisk og i noget mindre omfang analytisk og empirisk objekt. I denne artikel er perspektivet at analysere kroppens betydning i subjektets tilblivelsespræmisser. Vi er gået på jagt efter begreber og tænkemåder, som viser sig brugbare som analyseredskaber i mødet med empirisk materiale, som omhandler subjektiveringsprocesser. De kroppe, $v i$ altså interesserer os for, er kroppe, som på forskellige måder, kan fortælle os noget om de måder, vi bliver til som - ikke mindst kønnede - subjekter. Denne interesse skal forstås inden for en feministisk, poststrukturalistisk tænkning, der interesserer sig for subjektivering og levet liv (Søndergaard 2003, 1996, Staunæs 2004, 2003, Davies 1993, 2000), tænkt i gennem poststrukturalistiske (Butler 1993, Foucault 1976, 1994) og diskursteoretiske tilgange (f.eks. Wetherell, Taylor and Yates 2001). ${ }^{1}$ Efter- 
som videnskab er en sprogligt baseret gerning, og fordi vi lever med en sprog/kropdualisme, der ser de to størrelser som radikalt adskilte - den ene gennemsigtig og tilgængelig, den anden uoversættelig og oprindelig - kan kroppen have en tendens til at undslippe videnskabelig italesættelse. Selv inden for diskursteoretisk inspirerede analyser af subjektivering - hvor diskurser og diskursive praksisser ikke kun omhandler sproglige ytringer, men en langt bredere forståelse af sprog som tegn eller betydningssætning mere generelt - forsvinder de kropslige aspekter af subjektiveringen ofte ud af analysen. Men når vi taler om processer, der danner os som subjekter bliver en forståelse, der udelukkende behandler disse processer som sproglige/diskursive aktiviteter let ensidige eller tynde, idet de aspekter af subjektivering, der angår kropslige dynamikker åbenlyst, er af afgørende betydning for, hvordan og hvad vi bliver til som subjekter. Derfor spørger vi i denne artikel: Hvordan kan man gribe 'krop' i empiriske analyser? Og hvad er det for en krop, man får greb om, når man således griber?

\section{IMOD DEN GENERELLE KROP}

Men hvorfor overhovedet gå til poststrukturalisme, når en række andre teorier tilbyder deciderede kropsperspektiver? Fordi vi oplever, at kropsteorier producerer en generel eller generaliseret krop, som i for høj grad låser den empiriske analyse. Lad os komme med et eksempel. Iris Marion Youngs interessante fænomenologiske analyse af pigers kroppe kan belyse problematikken. I artiklen "Throwing like a girl" undersøger Young grundene til drenge og pigers væsensforskellige kasteteknikker. Hun konkluderer, at under pigers opvækst inden for en patriarkalsk struktur bindres deres rækken- eller kasten-sig-ud i verden af en stadig holden-sig-tilbage. Der lægger sig en modsatrettethed i kroppen, idet piger lærer at opleve sig selv som objekter, og på denne vis kommer piger til at kaste som kraf- tesløse piger, der alene bruger håndledet frem for hele kroppen til at kaste med. At (op)leve sig som subjekt gennem en sansende og sanselig krop, der netop uhindret rækker ud i verden, er et knudepunkt i fænomenologiens kropsteori; denne væren krop-i-verden er generel menneskelig; men, viser Young, (ud)leves dog maximalt af $\mathbf{5 0}$ procent af patriarkalske samfunds befolkninger. Ved den fænomenologiske analyse er Youngs kritiske potentiale argumentet, at der findes en (generel, naturlig) krop, som piger og kvinder hindres $i$ at være. Det er en væsentlig kritik. Som vi ser det, er der med fænomenologien tale om et konkret kropsideal maskeret som kroppen generelt. Kropsidealet er reelt defineret efter en hegemonisk model, og derfor udgrænser den allerede som analysekategori kvindekroppe som manglende. Tillige afgrænser idealet alternative/ ikke normative mandekroppe, der opfattes som mangelfulde og forkerte, såvel som det sætter den hegemoniske mandekrop uden for en kritisk analyses rækkevidde.

Hvad så? Skal man råbe "dur ikke" efter fænomenologien, og lede til man finder en teori med et generaliseringspotentiale til at inkludere flest af alle jordens kroppe? Skal man lede efter dén kropsforståelse, der er mest kropsligt sand eller bedst? Eller kunne det måske være frugtbart at aflyse en sådan jagt, og i stedet prøve at begribe kroppen anderledes? I teoretikeres omgang med kroppen ser man ofte, at kroppen bliver til et særligt sted. Enten ved at man privilegerer kroppen (én krop); som fænomenologien gør det, eller ved at kroppen skrives ud af analysen og bliver til dét, man ikke kan analysere, som en lang række andre gør det. Den besværede omgang med kroppen er ikke mindst produkt af de effekter, som dualismer såsom bevidsthed/krop har på såvel hverdagsforståelser og -gørelser som på teoretiseren. ${ }^{2}$ Denne dualistiske apriori indebærer, at kroppen bliver et subjektiveringsspor, som umiddelbart altid allerede er sat uden for sproglig erkendelse. Kirsten 
Hastrup har følgende analyse af bevidsthed/kropsproblematikken:

[..] the apparently theoretical problem of reuniting mind and body as the locus of action is it-self constituted within a specific discourse that separated them in the first place. Therefore, we do not necessarily have a serious epistemological obstacle. What we do have is $a$ problem of wording: like the prophet, we lack the words for, rather than the experience of, the unity of body and mind. (Hastrup 1994, kursiv tilføjet)

Ifølge Hastrup er der altså ikke tale om et uoverstigeligt epistemologisk problem alt den stund, at vi pr. erfaring ved, at bevidsthed/ krop ikke er adskilte entiteter. Det skulle altså være et spørgsmål om at finde ord, som formidler erfaringerne anderledes. Men, kunne man indvende, erfaringer er jo erfaringer i og af en verden - en verden, som allerede er diskursiveret med kropsekskluderende dikotomier. Derfor kan det være frugtbart at gå et skridt tilbage og overveje det metateoretiske grundlag for krops-ordforrådet, hvis nye, anderledes, eller/og allerede kendte kroppe skal finde vej til "wording" eller begrebsliggørelse. ${ }^{3}$

\section{BEGREBER OM KROP}

Nedenfor vil vi kort skitsere artiklens grundlag under overskrifterne: Kroppen $i$ tilblivelsesprocesser, kroppen i intra-activity, kroppen $i$ mellem sedimentering og forandring.

Artiklen er skrevet ud fra en poststrukturalistisk, feministisk optik og henter sin primære inspiration i arbejder af Karen Barad, Judith Butler og Bruno Latour, mens de konkrete analytiske greb er blevet til med udgangspunkt i vores igangværende arbejder. Arbejderne rummer empirisk materiale i form af kvalitative interview samt hverdagslivsobservationer; det vil sige observationer af interaktioner, kropslige bevægelser og samtaler fra børn/unges skoleliv. Med dette righoldige materiale bliver det muligt at forpligte og udfordre de teoretiske optikker gennem empiriske analyser.

Som et analytisk udgangspunkt aflyses den generelle krop. Når vi aflyser den generelle krop, mangedobler vi de steder og måder, man kan få øje på kroppen som medkonstituerende i subjektiveringsprocesser. Kroppen bruges som en analytisk indgang til at åbne op for nye dimensioner af subjektets komplekse og stadige kommen til eksistens. Konsekvensen af denne tilgang bliver, at spørgsmålet om hvad en krop overhovedet er for en størrelse, hvor kroppen går til/fra, hele tiden bliver et empirisk, analytisk situeret anlæggende. Vi åbner for - generel - analytisk sensitivitet overfor, at kroppe indgår $\mathrm{i}$ den løbende subjektivering (frem for primært at være sproglige begivenheder), og at denne indgåen finder sted på forskellig vis i forskellige (empiriske og analytiske) situationer.

\section{Kroppen i tilblivelsesprocesser}

Artiklen anlægger en processuel tilgang til kroppen. Herfra læses kroppen ikke som et afgrænset sted eller en container, men forstås derimod som tilblivende, dvs. som til stadighed i gang med at blive skabt og omskabt i en spænding af sedimentering (dvs. træghed) og forandring. ${ }^{4}$ I løbet af en dag er subjektet indlejret i et væld af processer processerne er forskelligartede og har forskellig varighed, tyngde og rækkevidde (i tid og rum). Nogle processer løber sideordnet, og andre krydser hinanden og skaber i dette møde nye subjektiveringsspor, dvs. nye værens- og tilblivelsespræmisser. Tilgangen er inspireret af Judith Butlers kendte og berømmede arbejde. Butler skriver, at krop og køn fremkommer gennem gentagende citation og performativitet, altså $\mathrm{i}$ stadig tilblivelse gennem diskursive praksisser. Butler lader sig læse på mangfoldige måder. Hendes udsagn om, at vi ikke har nogen præ-diskursiv adgang til krop og køn får nogle læsere til at indvende, at med Butler får vi en sproglig krop i hænderne. (Kir- 
by 1997, Butler 2001) Og at dette ikke er 'den egentlige krop'. Andre vil hævde, at dén kritik beror på en misforståelse af Butlers diskursbegreb (Søndergaard 1996, 2003, Davies 2000). Selv kalder hun problematikken diskurs/materialitet for en ordgåde (frem for en dikotomi): Kroppen har en vedholdende, pågående, kropslig materialitet, men den lader sig aldrig kende uden for den kulturelle artikulation, som den fremkommer i. Dette betyder ikke, at kultur producerer kroppens materialitet. Men det betyder, at kroppen altid er givet til os i en eller anden form, og at den form - som den kulturelle affirmation af kroppens materialitet tager - vil bidrage til "the very matter that it names." (Butler 2001, 12) Hvorom alting er kan vi bruge Butlers arbejde som platform for videre tænkning.

\section{Kroppen i intra-activity}

Vi ser kroppen, analytisk, som relationel og situationel: Kroppen indgår og folder sig sammen med andre og andet; med andre kroppe, med billeder, med artefakter, med (betydningsmættede) rum etc. ${ }^{5}$ Kroppen er altså hele tiden tilblivende - situationelt med andre 'elementer'. Her bliver det nødvendigt at udvide perspektivet fra det Butlerske. Butler interesserer sig for kroppen på grund af kønnet, og det kan indebære, at analyseblikket for hurtigt retter sig mod nogle bestemte relationer og processer, således at man simpelthen taber elementer og dimensioner ud af syne, som er betydningsfulde for begribelsen af kompleksiteten i de kropslige (og sanselige) subjektiveringsprocesser. En udvidelse af det analytiske synsog begrebsfelt går for os via Karen Barad og Bruno Latour. ${ }^{6}$ Begge tilbyder de materialitet en ny teoretisk status, ikke mindst fordi deres foki er bredere end menneskekroppen - og det hjælper os til at tænke kropslig subjektivering anderledes analytisk åbnende.

I det nærværende bliver det nødvendigt at gøre en lang (meta)teoretisk problematik meget kort:

Barad arbejder med Butlers performativi- tetstænkning, men med den kvalitative forskel, at performativitet ikke er "iterative citationality (Butler) but rather iterative intra-activity”. (Barad 2003, 828. Kursiv tilføjet). Modstillingen mellem citationalitet og intra-activity henviser til, at Barad ser Butlers citationalitetsbegreb som antropocentrisk; hidrørende mennesker, menneskekroppe og diskurser. Barad, med sin baggrund i naturvidenskaben, inkluderer 'matter', så bredt forstået som muligt, samt giver 'matter' en anderledes medkonstituerende betydning - og lad os lige opholde os herved et øjeblik, inden begrebet 'intra-activity' udfoldes yderligere: Diskursive praksisser er ikke ord, men konfigurationer, de er "ongoing material (re)configurations of the world" (Barad 2003, 821-2). Dette skal ik$k e$ forstås således, at der også er noget materielt $\mathrm{i}$ det diskursive, sådan som det ligger $\mathrm{i}$ Butlers begrebssætning. ${ }^{7}$ Her er ikke blot tale om en nuancering af diskursbegrebet. Pointen om det materielle og diskursive er: "the conjoined material-discursive nature of constraints, conditions and practices" (Barad 2003, 823). Hverken diskursive praksisser eller materielle fænomener er ontologisk eller epistemologisk forud for hinanden. Som konsekvens kalder Barad tilblivelsesprocesser for materielle-diskursive praksisser. Scoopet med Barad er netop den måde, hun begrebsmæssigt får udfoldet det simultane i materielle-diskursive praksisser som eksemplificeret ved begrebet intra-aktivity: "Intra" skal forstås i sin modsætning til "inter", som signalerer sammenkoblinger mellem på forhånd afgrænsede, uafhængige entiteter. Med 'intra' understreges det, at intra-actions er begrænsende, men ikkedeterministiske "enactments" gennem hvilke "matter-in-theprocess-of-becoming" sedimenteres og foldes ind i videre materialisation/materialisering. (Barad 2003, 823). De materielle-diskursive praksisser er altså praksisser af intra-aktivitet; praksisser, som eksempelvis skaber og grænsesætter forholdet 'human'/'non-human': praksisser, hvorigennem virkelighed, kroppe, subjekter kommer til mening og materi- 
alitet (hvor 'mening' altså netop skal læses som materielt-diskursivt - og ikke som ordog materialitet skal læses som tilblevet og tilblivende i og med intra-aktivitet - dvs. ikke som ting.).

Den videre udfordring ligger så i at tænke med denne simultanitet, empirisk og analytisk, det vil sige, at gå på den anden side af eller at gå ind i de adskillelses(tilblivelses)processer, hvor 'noget' fremstår for os som en entitet - dvs. adskilt og afgrænset, såsom kroppen adskilt fra rummet, tanken adskilt fra kroppen (eller som vi skal behandle lidt senere - kroppen adskilt fra medierepresentationer). Den analytiske gevinst er blandt andet, at det bringer os på den anden side af det noget uproduktive spørgsmål om, hvorvidt det er diskurser eller materialiteter, som er 'handlende', har agens og genererer forandring og sedimentering; det åbner mulighed for at se tilblivelsesprocesserne med en anden kvalitet af kompleksitet.

Lad os prøve at tage Latour til indtægt for samme type tænkning og bringe et eksempel på en sådan "intra-actional” proces: Latour anvender i artiklen "How to Talk About the Body? The Normative Dimension of Science Studies" (Latour, 2004) eksemplet, bvordan man laver at blive en 'nese'. En næse er betegnelsen for mennesker ansat i parfumeindustrien til at skelne mellem lugte, som de fleste andre mennesker ikke kan skelne. I uddannelsen til at blive en 'næse' indgår en værktøjskasse med flakoner indeholdende en rakke skarpt adskilte dufte arrangeret sådan, at man kan gå fra flakonerne med de skarpeste kontraster til dem med de svageste kontraster. I løbet af en uge går de, der ender som 'næser' fra kun at kunne skelne de mest kontrasterende dufte fra hinanden til en langt mere differentieret lugtesans. Således bliver vi til som kroppe gennem sanselig intra-aktion med verden, ligesom verden bliver til for os gennem vores sanselige intra-aktion med den. Vi skal ikke betragte kroppen og verden som adskilte enheder, men snarere se dem som tilblivende i og med intra-aktivi- tet, som sætter kvalitative forskelle. Latour taler om dette som en læreproces, som en kvalitativ forandrings-skaben: "To have a body is to learn to be affected", siger han også (Latour 2004, 205).

\section{Kroppen $i$ mellem sedimentering og forandring}

Latours pointe er, at vi som mennesker omgås og formes af vores omgang med andre - ikke mindst andre ikke-menneskelige aktanter. Det eksempel, Latour giver med næsen, viser samtidig, at vores kroppe i disse intra-aktioner hele tiden gennemgår læreprocesser, hvor vores sanseregistre udvides og forandres. Men disse intra-agerende kropslige og sanselige registre har dynamikker af både forandring og sedimentering, og det er vigtigt for vores arbejde at finde måder at (be)gribe kropslig subjektivering netop i kvaliteten af både forandring og sedimentering. Disse dynamikker ser vi ikke som adskilte, men som kvalitative forskelligheder i en proces. Her følger vi principperne i Butlers citations- og performativitetstænkning, hvor den korte udlægning er, at enhver tilstand er en proces af stadig gentagelse, et stadigt arbejde med at ekskludere 'noget andet', og gentagelsen af denne udelukningsproces producerer automatisering, naturalisering og materialisering - eller med en samlende betegnelse; sedimentering. Herigennem formes og vanesættes kroppen. Subjektiveringen lægger sig som spor i kroppen, og hermed løber den kropslige subjektivering ganske automatiseret og træghedsproducerende. Samtidig er de kropslige sedimenteringsprocesser instabile. I kraft af gentagelsen åbnes for "gaps and fissures", en instabilitet som Butler netop udpeger som "the deconstituting possibility in the very process of repetition, the power that undoes the very effects by which 'sex' is stabilized" (Butler 1993, 244-5). Med andre ord rummer sedimenteringsprocesserne forandringspotentialer.

Med disse teoretiske redskaber i rygsækken skal vi nu begive os ind i et subjektive- 
ringslandskab, og se på hvordan en analyse af et stykke empiri kan se ud, hvis vi forsøger at tage vores tre metateoretiske dimensioner i ed.

\section{INDFOLDNING AF KROP OG BILLEDER}

Vi har valgt et empirisk eksempel, som viser, hvordan subjektiveringstilblivelser bl.a. følger spor, hvor kroppen gennemløber indfoldningsprocesser med medierepræsentationer. En meget udbredt måde at tænke forholdet mellem medierepræsentationer og subjekter er ved at forstå dem som to stabilt, adskilte størrelser. Denne type tænkning har ført til et utal af diskussioner om, hvorvidt medier påvirker mennesker eller mennesker læser betydning ind i medier ( $\mathrm{Se}$ eksempelvis Drotner 1999), diskussioner hvor man enten skal vælge side som tilhænger af ideen om subjekter som tomme skaller, der får indprentet mediernes budskaber eller af ideen om subjekter som rationelt vælgende individer, der betydningssætter medierepræsentationer, så det gavner deres livsprojekt. Med vores processuelle intraaktivitetstænkning, hvor kroppe bliver til mellem forandring og sedimentering, bliver det muligt at overskride denne statiske dikotomi mellem medierepræsentationer og reciperende subjekter og i stedet anskue både medier og mennesker som processuelle størrelser i en stadig tilblivelsesproces. Snarere end at spørge til hvem/hvad der påvirker hvem eller hvad, vil vi altså åbne for analyser af, hvordan både subjekter og deres kroppe samt medierepræsentationer 'bliver til' i mødet med hinanden. Hermed udfoldes, gennem det empiriske eksempel, 'en anden krop' og en anderledes forståelsesmulighed for de subjektiveringsprocesser, hvori medier medkonstituerer identitet.

Det kan vi starte med at gøre gennem Latour der, som nævnt, tænker kroppen som en proces, der retter sig mod at lære at blive påvirket, bevæget eller sat i bevægelse af andre enheder, menneskelige eller ikkemenneskelige. Latour udfordrer os netop med sit 'næse'-eksempel til ikke at se krop og verden og medium som adskilte entiteter, men snarere som en proces hvor de tre instanser folder sig ind $i$ hinanden og gensidigt skaber forandringer samt sætter nye betydninger i hinanden. Denne udfordring vil vi tage op ved at se på mediebilleder som en medierende instans, der på linje med 'næse'lærlingenes duftværkstøjskasse indgår i subjekters kropslige læreprocesser. De kroppe, der intra-agerer med medierne, gives mulighed for at sxtte og opfatte nye betydninger af verden, ligesom duftværktøjskassen gav næserne adgang til nye betydningssætninger. ${ }^{8}$ Hvor mange mediereceptionsanalyser fokuserer på et diskursivt eller sprogligt niveau, giver Latours 'næse'-eksempel os adgang til at fokusere på et kropsligt sanseligt niveau: Duftværktøjskassen giver anledning til en læreproces via lugtesansen og til en kvalitativ forandring i næsen og i næsens oplevelse af verden, mens mediebillederne oplagt snarere er en læreproces, der går via blikket og som vi, med Latour, må forestille os er med til at forme og forandre dette blik - ligesom blikket, som det vil blive klart, også former og forandrer mediebillederne. Vi har valgt et eksempel, som gør det klart, at blikket kobler sig til en række andre kropslige registre og sanser og som samtidig peger på, at synssansen i allerhøjeste grad også er et kødeligt anliggende.

Lad os se hvad 16-årige Mette siger om reklamebilledet M7 fra Yves Saint Laurent, for at anskueliggøre hvordan en analyse af en kropslig og billedlig indfoldet tilblivelsesproces kunne tage sig ud. Mette og jeg kigger på billedet, der viser en nøgen mand, der sidder lænet tilbage med spredte ben, så hans (ikke-erigerede) penis kommer til syne i billedets nederste mørke del. Resten af billedet viser mandens overkrop og ansigt, der vender siden til og kigger nedad. Mette udbryder:

M: Den er klam.

I: Hvad er det klamme ved den?

M: Det er altså, at han ikke har noget tøj på 
...Fordi der ser man næsten hele hans krop. I: Er det det der med, at man ser hans kønsdele faktisk eller hans tissemand? $\mathrm{M}$ : Ja, det synes jeg, det er klamt. ...

I: Hvorfor er det værre?

M: Fordi så er der nogle måske, der får billeder inde i hovedet.

I: Hvad făr man billeder af?

M. Der er nogle, de kan få sexbilleder, hvis man var lille pige, få nogle tanker om den der M7..

I: Hvad kunne det være?

M: Der ville få sextanker, det ville jeg da, hvis jeg var sådan en lille en.

I: Hvad ville det være f.eks.?

M: Man sidder måske og bladrer i et blad, og så ser man det der billede, og så sidder man bare, det er svært med tankerne, for lige pludselig slipper ens tanker bare løs, og så tænker man bare på det billede, altså det har jeg da også haft nogle gange i et blad, hvor man bare sidder med sådan en reklame, så sidder man bare og kigger og stirrer på den i 10 minutter måske og får tankerne til at køre og siger bare o.k.

I: Så kommer der alle mulige tanker?

M: Så kommer der sådan nogle tanker op i hovedet om den reklame, hvad man inderst inde godt ved, at det vil ikke ske, for det er jo bare en reklame.

...

I: Hvad ville der være det ubehagelige ved det, altså hvordan, kan du sige lidt om det? $\mathrm{M}$ : Ja at man er lille, og så tænker man over for meget med vold og sådan noget, når man har set en eller anden reklame, og man går alene på en vej, så føler jeg sådan, nej der går en mand, og så kommer jeg til at tænke på den reklame, fordi man sådan ja o.k., det er altså ubehageligt det der. Det får jeg også nogle gange, når jeg sidder og ser en reklame, hvis det nu var den der med M 7, så ville jeg da også få sådan, hvis jeg mødte ham på en vej, så ville jeg da sgu være bange.
Mette beskriver, hvordan mødet mellem billedet og Mette giver "billeder inde i hovedet". Vi kan forstå denne fortælling, analytisk, som en Baradsk indfoldningsproces, hvor billede og blik/hoved/krop ikke længere er adskilte enheder, men er blevet en del af hinanden, er blevet gensidigt konstituerende og svære at skelne i mellem. I en Latoursk optik ville vi tale om at den proces, der er opstået i mødet mellem krop og billede har skabt kvalitative forandringer $\mathrm{i}$ både billede og krop - Mette har på den ene side fået billeder i hovedet og M7 billedet er blevet multipliceret, har forvandlet sig til en række af billeder. Hun mener selv, at denne proces er sat i gang af mandens afklædthed, ved synet af den opstår der i Mette en følelse af afsky ("han er klam") og af noget seksuelt ("sexbilleder" og "sextanker") og med disse følelser, synes en proces at være sat i gang; det er ikke bare M7-billedet, der er kommet ind hovedet, men billeder (i flertal) og tanker der ikke kan styres. Propelleret frem af klamheden og sexbillederne har mødet mellem billedet og kroppen resulteret i en proces, en produktion af flere og nye billeder og tanker i Mettes krops-billede-indfoldning. Mettes beskrivelse viser os, at der næppe bare er tale om, at hun med et abstraheret, ukødeligt blik kigger på et billede, som hun derefter producerer en kropsrenset kognitiv, reflekteret diskurs på baggrund af, men snarere at hele processen er en stor intra-aktion af blik, billede, krop, kødelighed, sanser, tanker, seksualitet, afsky og lyst - og at Mette gennem denne proces bliver til en anden krop.

Men hvordan skal vi forstå Mettes betydningsproduktion af M7 reklamen? I vores betydningsproduktion viser billedet nemlig ikke, som man måske skulle tro, en faretruende, aggressiv mand, der sidder på spring til sin næste voldtægt, ${ }^{9}$ men tværtimod en passiv, seksualiseret og indbydende mand. Billedet vakte furore, da det kom frem; mandens passive udtryk kombineret med hans totale nøgenhed fik mange til at anse billedet for bøsseerotica, og billedet fik da 
også ikonstatus i visse mandlige homoseksuelle kredse. Hvordan er Mette kommet frem til at betydningssætte dette billede som vi og en hel del homoseksuelle mænd er enige om, er et billede på mandlig, seksuel tilgængelighed - som en voldtægtsmand? Og hvordan skal vi forstå den produktion af billeder i Mettes hoved, der øjensynligt propelleres frem af en blanding af seksuel lyst og afsky?

For at forstå dette må vi tage en lille ekskurs ud $\mathrm{i}$ andre dele af interviewet med Mette og i resten af materialet om unges forhold til seksualiserede medierepresentationer; seksuel lyst og afsky er til stede i adskillige af interviewene med pigerne, især når talen falder på musikvideoer, som de både har et fascineret og ambivalent forhold til. Det manifesterer sig i, at flere af dem både vælger stærkt seksualiserede videoer som deres yndlingsvideoer, hvor letpåklædte damer fungerer som blikfang og begærsobjekter, og at de samtidig ser bort fra og føler ubehag ved de seksualiserede kvinder. Når pigerne må se bort fra en sanselig fascination af de seksualiserede videoer, ser det ud til, at det bl.a. er et spørgsmål om, at en lystfyld, sanselig og seksuel fascination af videoerne, kvinderne og de mandlige stjerner afbrydes eller kortsluttes af en ubehagelig oplevelse af at blive positioneret problematisk, fordi de deler kategori-tilhørsforhold med kvinderne i videoerne. Den orkestrering af det heteroseksuelle forhold, som stort set alle disse videoer bygger på med en mandlig begærer og en kvindelig begæret, udelader seksuel agens fra den kvindelige position og åbner for en potentiel ubehagelig (hun er billig) eller farlig position som 'taget' ('imod sin vilje'.) I musikvideoerne spilles der ofte på ideen om kvinderne som mændenes tilbehør - "pussy" som en af drengene $i$ et interview beskriver kvindernes funktion - og pigerne er sig smerteligt bevidst om disse som upersonlige, nedgjorte og offerkonnoterende positioner, de ikke ønsker at indtage, samtidig med at positionen som begæret ofte er eftertragtet.
Hvis vi vender tilbage til Mettes tolkning af M7-manden som en potentiel voldtægtsforbryder med denne analyse i baghovedet, kan vi tolke hendes læsning af billedet som udtryk for dels et stadigt sedimenterende blik: Seksuel agens er i gennem så mange gentagende processer slået fast som en mulighed, der udelukkende er knyttet til mandekroppen, at Mette kun kan se M7 manden som en variation over den tagende mand og sin egen position som den seksuelt tagede. Samtidig betyder den seksuelle appel som billedet udsender, at den indfoldning af blik, krop og billede som foregår, har en særlig karakter. Fra studier af pornografi ved vi, at de fleste mennesker har svært ved at lade være med at reagere fysisk på billeder af seksualitet - kroppen har en tendens til at svare fysisk på billederne bl.a. med øget blodtilførsel til kønsorganerne og sekretudsondring, uanset om kroppens reaktion er ønsket eller ej (se eks. Berg 1999). ${ }^{10}$ I hvilken grad den sanselighedsproces, der går i gang i Mette, har karakter af en sådan fysisk seksuel reaktion, aner vi ikke, men sammenligningen kan skærpe vores opmærksomhed på de kropslige eller fysiske elementer i sanselighedsprocessen, den agens kroppen også har i fortolkningen og reaktionen på billedet.

Hvis vi skulle gå videre i en spekulation om et sanseligt lystaspekt af Mettes indfoldede og kropsbevægede møde med M7 billedet, kunne vi hæfte os ved hendes fortællings mange brud; måske presser andre typer af fortællinger og oplevelser sig også på i hende? Fortællinger, sanseligheder eller følelser som ikke passer ind i hovedfortællingen om manden som voldtægtsmand og måske forskydes fortællingen til en mindre pige, fordi der samtidig rumsterer en tavs ikke udtalt fortælling om en større pigekrop, der har adgang til seksuelle lyster? Når Mettes sedimenterede blik møder den nøgne, seksualiserede mand på billedet, kan vi på denne baggrund, og på baggrund af Mettes fortælling om at M7 billedet sætter en ukontrollabel proces i gang, forestille os, 
at mandens nøgne krop berører hendes blik i en blanding af en sansemættet, seksuel taktilitet og et angreb - en kommen i mod hende, en farvning eller berøring af hendes blik, en indtræden i hendes hoved, der sætter en automatiseret sanselighedsproces i gang. Denne sanselighedsproces er måske, som pigernes ambivalente forhold til de seksualiserede videoer, karakteriseret ved en blanding af seksuel lyst og afsky og indeholder en række ustyrlige billeder, tanker og følelser, som følger en heteroseksuel orkestrering af det seksuelle møde mellem en mandlig tager og en kvindelig taget. Når Mette fortæller, at "man bare sidder og stirrer i 10 minutter og får tankerne til at køre", peger hun på, at intra-aktionen mellem hende og billedet skaber et sanseligt ophold, et øjeblik som giver anledning til en proces, der formentlig følger flere modsatrettede spor. Umiddelbart giver udsagnet måske associationer af et lystproduceret ophold ved den nøgne mandekrop, men Mette selv betydningssætter snarere opholdet som en angstpræget paralyse, så lad os antage, at der er tale om i hvert fald begge disse processer. Desuden giver hendes udsagn indtryk af, at processen har et udstrakt tidselement i sig. Der er tid til, at handlingssekvenser kan gennemspilles, og hun giver os selv et eksempel på et sådant forløb, når hun fortæller om angsten for at møde voldtægtsmanden på en stille vej. Vi må med andre ord også konceptualisere de tanker og billeder som Mette får inde i hovedet som deciderede handlingssekvenser frem for som fastfrosne stillbilleder.

De sekvenser Mette giver os adgang til at fremanalysere, kredser om handlingsforløb, hvor mænd kan gøre noget med kvinder, hvor mandens monopol på seksuel agens bruges til at gøre noget voldeligt eller ubehageligt ved pigerne/kvinderne. Uanset om sanselighedsprocessen også indeholder deciderede lystspor, ser den i Mettes univers ud til at ende med at placere hende i positionen som ubehageligt taget; "pussy", voldsoffer og den må derfor kategorisk afvises.
Den intra-aktion, Mette og billedet af M7 har med hinanden, kan (kort opsumeret) beskrives sådan, at når Mettes sedimenterede blik kastes på den nøgne, seksualiserede mand, så berører mandens nøgne krop hendes blik i en sansemættet, seksuel taktilitet, der sætter en automatiseret sanselighedsproces i gang. Vi kan spekulere over om ikke den udvidelse af Mettes sanseregister, som hendes billedindfoldede kropsbevægede intra-aktion med M7 har resulteret $i$, har udfordret hendes sedimenterede blik, hendes kropsindlejrede positionering som passivt seksuelt objekt i en seksualiseret relation ved at tilbyde hende positionen som aktiv seksuel tager og lystindehaver. Men den kropslige affekt, som billedets sanselige appel sætter i gang - sanselighedsprocessen med dens række af modsatrettede lyst, afsky, angstspor - suges ned i ét spor, som i et sort hul eller som af en tyngdekraft af materialiserede erfaringer, som over tid har sedimenteret sig til en kropslig-diskursiv automatiseret positionering som objekt; som taget. Sanselighedsprocessen ender derfor med at positionere Mette som offer, en positionering som hun reagerer på ved at støde den bort som "klam" og samtidig hive sit blik ud af det sansemættede, taktile møde med mandekroppen.

Ud af den strøm af modsatrettede sanselighedsspor og positioneringsmuligheder fremkommer den kropsligt erfarede sedimentering af positioneringen som seksuelt objekt - taget - som en opstået entitet, et diskursivt-materielt 'cut' er foretaget og positioneringen som lystsubjekt, sanselighedsspor af seksuelle lyster, etc. sættes som denne sedimenterede erfarings konstitutive yderside, det som absolut ikke hører til Mettes mulige positionering. Voldtægtsmanden og hans offer bundfælder sig, materialiserer sig som stabile betydninger, mens den seksuelt tilgængelige objektgjorte mand og den lystudøvende pige, sættes uden for grænsen af den stabiliserede betydning og af den kropsligt sansende erfaring. Men som Butler lærer os, er konstitu- 
tive ydersider ikke negative og betydningstomme, men tværtimod virksomme som dekonstituerende muligheder. Den læreproces som Mettes krop har gennemgået i mødet med M7 billedet har således resulteret $\mathrm{i}$ en sedimentering af positionen som taget offer, men har samtidig aktualiseret en konstitutiv yderside af positionerne som aktiv tager, der, hvem ved, måske en dag får magt til at rykke ved offerpositioneringens stabiliserede betydning?

I analysen af interviewet med Mette gives et bud på, hvordan kroppe og andre materialiteter - som mediebilleder - indgår som betydningsfulde medspillere i de vedblivende processer, der hele tiden danner os, og som vi danner os gennem som subjekter. I denne analyse har vi sat fokus på en potentielt medkonstituerende aktør - M7 billedet - i en ung piges tilblivelse som kønnet og seksuelt subjekt. De kropsanalytiske redskaber vi har anvendt fra Butler, Barad og Latour har muliggjort analyser, som fokuserer på de måder subjektiveringsprocesser foregår materielt, dvs. både de kropslige processer subjektet selv er involveret $i$, og de materialiteter eller andetheder som subjektet formes sammen med. Med Barads indfoldning og intra-aktivitets begreb, Latours forståelse af de ikke-menneskelige materielle aktanters kropsbevægende indflydelse og Butlers performativitets og sedimenteringsbegreb, er det lykkedes os at komme på den anden side af konventionelle måder at tænke distinktionen mellem kroppe og 'ting', bevidstheder og kroppe, sprog og krop etc. og skimtet en anden type krop, en bestræbelse som vi synes, det virker lovende at videreudvikle.

\section{Noter}

1. Det som karakteriserer subjektiveringstilgangen er en stadig oversættelse og viderebearbejdning af det ofte meget generaliserede og overordnede poststrukturalistiske tankegods. Konkretiseringerne sigter på at begribe et subjektnært 'levet liv'. Her ses subjektivitet som diskursive praksisser i or- dets bredest mulige forstand - åben for forhandlinger og konstruktioner, men også organiseret i forhold til historiske og kulturelle forståelser af kategorier som køn, klasse, race, etc. som individet bliver til som subjekt gennem. Det er en analysetilgang, som tager udgangspunkt i et begreb om subjektivering, der netop rummer den dobbelthed - som efterhånden er blevet en udbredt Foucaultparafrasering - at subjektet både bliver underlagt, men samtidig bliver til og får handlemuligheder gennem sin diskursiverede subjektivering.

2. Om "gørelser" se note 3 .

3. Inden for den tænkning, som artiklen gør sig til del af, anskues sproget som performativt. Derfor er der en opmærksomhed på at arbejde nye sproglige præciseringer frem. Det stiller i sagens natur nogle udfordringer til læseren. Se Kofoeds artikel i nærværende nummer for en diskussion udfoldet omkring elevhed/“at gøre elev”. Se Søndergaard 1996 for "kønsgørelser".

4. Sedimenteringsbegrebet forklares i afsnittet Kroppen i mellem sedimentering og forandring.. 5. Foldebegrebet udvikles bl.a. af Deleuze.

(1986/1988, 1988/1993), som henter begrebet hos Foucault og bruger det til at destabilisere dikotomien 'indenfor' og 'udenfor'. Eftersom foldens inderside bliver dens yderside et andet sted eller på et andet tidspunkt (hvis folden er i bevægelse), ophæves et absolut skel mellem de to, ligesom spørgsmålet om hvad der egentlig konstituerer 'udenfor' og 'indenfor' aktualiseres og destabiliseres. I den forstand er folden også et billede på Deluezes intention om at opbryde humanistiske dualismer generelt. Barad bruger foldebegrebet uden en egentlig begrebsdefinition, men i hendes intention om at opløse en skelnen mellem to afgrænsede enheder der mødes eller støder sammen og i stedet signalere en gensidig konstituering og en uafklarethed omkring grænserne mellem det ene og det andet (eksempelvis kroppen og det andet), viser Deleuzes binaritetsopbrud sig. For en uddybning af foldebegrebets historie se Adams, 1997. 6. Latour er videnssociolog. Barad har en baggrund i teoretisk fysik, filosofi og Women's Studies. 7. Se eksempelvis afsnittet "Are bodies purely discursive?" i Bodies that matter. 1993, 67-72.

8. Af formidlingshensyn er vi i denne forklaring trådt et skridt tilbage i vores kropsteoretiske gennemgang og holder fast i en alment genkendelig forståelse af entiteter - kroppe, mediebilleder, verden - som afgrænsede størrelser, men hensigten er altså i det kommende at demonstrere hvor sammenfiltrede de er.

9. At den vold Mette taler om er voldtægt, bliver tydeligt senere $\mathrm{i}$ interviewet. 
10. Eksemplet er ikke et forsøg på at placere seksualitet som en slags adgang til en 'oprindelig og $æ g$ te kropslig krop', det frnomen, at mennesker reagerer fysisk på billeder af seksualitet kan i vores optik forstås som et udslag af en kulturel placering af seksualitet som noget privilegeret, sanseligt påvirkende - en placering der er produceret igennem gentagende indfoldningsprocesser mellem kroppe og billeder, fortællinger og oplevelser af seksualitet.

\section{LITTERATUR}

- Adams St. Pierre, E. (1997): "Methodology in the fold and the irruption of transgressive data". I Qualitative Studies in Education. Vol 10, No. 2, pp 175-189.

- Barad, K. (2003): "Posthumanist Performativity: Toward an Understanding of How Matter Comes to Matter". I Signs: Journal of Women in Culture and Society. Vol 28, issue 3. pp 801-831

- Berg, L. (1999): Lagom är bäst - Unge kvinnors berättelser om heterosexuell samvaro och pornografi. Bilda Förlag, Stockholm.

- Butler, J. (2001): “There Is a Person Here": An Interview with Judith Butler. In International Journal of Sexuality and Gender Studies. Vol 6. nos $1 / 2,2001$

- Butler, J. (1993): Bodies that matter. On the discursive limits of sex. Routledge, London.

- Deleuze, G. (1993 (1988)): The fold: Leibniz and the baroque. University of Minnesota Press, Minneapolis MN.

- Deleuze, G. (1988 (1986)): Foucault. University of Minnesota Press, Minneapolis MN.

- Davies, B. (2000): A body of writing. 1990-1999, AltaMira Press, Oxford.

- Davies, B. (1993): Shards of Glass. Children Reading and Writing beyond Gendered Identities, Allen \& Unwin, Sydney.

- Drotner, K. (1999): Unge, medier og modernitet - pejlinger $i$ et foranderligt landskab. Borgen, Valby. - Foucault, M. (1994): Power. Essential Works of Foucault 1954-1984 (ed. Fabion, J.D.), The New Press, New York.

- Foucault, M. (1990 (1976)): The History of Sexuality. An introduction, Vintage Books, New York.

- Hastrup, K. (1994): “Anthropological knowledge incorporated". I Kirsten Hastrup og Peter Hervik (eds.) Social experience and anthropological knowledge, Routledge, London.

- Kirby, V. (1997): Telling Flesh, The Substance of the Corporal. Routledge, London.

- Latour B. (2004): "How to talk about the body? The Normative Dimension of Science Studies", in
Body \& Society Vol. 10(2-3): 205-229. Sage Publications, London, Thousand Oaks and New Delhi. - Staunæs, D. (2004): Køn, etnicitet og skoleliv. Samfundslitteratur, København.

- Staunæs, D. (2003): "Where have all the subjects gone? - Bringing together the concepts of intersectionality and subjectification" in Nora no. 2, Volume 11, 101-110.

- Søndergaard, D. M. (2003): “Subjektivering og Desire - begreber på empirisk arbejde" in Psyke \& Logos nr. 2. Dansk Psykologisk Forening. København.

- Søndergaard, D. M. (1996): Tegnet på kroppen. Køn: koder og konstruktioner blandt unge voksne $i$ akademia. Museum Tusculanum, København. - Wetherell, M., Taylor, S. and Yates, S.J. (2001): Discourse Theory and Practice. A Reader. Sage. - Young, I. M. (1990): Throwing like a girl. I Iris Marion Young (ed.) “Throwing like a girl” and other essays in feminist philosophy and social theory.

\section{SUMMARY}

Hunting through poststructuralist feminist theories of the body, this article presents building blocks for a theory of bodily subjectification processes which works against generalising ideas and which prove useful for complex analytical investigations of how we become subjects in a bodily sense. The building blocks presented includes 1) Viewing the body as in a constant process of becoming). 2) Conceptualizing the body in intra-activity with other elements - bodily becoming is dependent upon other bodies and artefacts with which the body infolds. 3) Setting the body between sedimentation and change. These ideas are drawn from Judith Butler's concept of performativity, Karen Barad's theorization of materialization processes and Bruno Latour's Actor Network Theory. The tools' workings are demonstrated on an empirical example of bodily infoldings between 16 yearold Mette and a sexualized commercial.

Sarah Højgaard Cawood, kandidatstipendiat Institut for Pædagogisk Psykologi Danmarks Prdagogiske Universitet

Malou Juelskjær, ph.d.-stipendiat Institut for Pædagogisk Psykologi Danmarks Pædagogiske Universitet 